\title{
Short Communication: \\ Growth patterns of Shorea leprosula and Dryobalanops lanceolata in Borneo's forest managed with Selective Cutting with Line Replanting System
}

\author{
MOHAMAD TAUFAN TIRKAAMIANA ${ }^{1}$, RUHYAT PARTASASMITA $^{2, \boldsymbol{v}}$, LEGOWO KAMARUBAYANA $^{1}$ \\ ${ }^{1}$ Department of Forestry, Faculty of Agriculture, Universitas 17 Agustus 1945 Samarinda. Jl. Ir. H. Juanda 80, Samarinda 75124, East Kalimantan, \\ Indonesia \\ ${ }^{2}$ Department of Biology, Faculty of Mathematics and Natural Sciences, Universitas Padjadjaran, Jalan Raya Bandung-Sumedang Km21, Jatinangor, \\ Sumedang 45363, West Java, Indonesia. ”email: ruhyat.partasasmita@unpad.ac.id; rp2010rikkyo@ gmail.com
}

Manuscript received: 20 February 2019. Revision accepted: 27 March 2019.

\begin{abstract}
Tirkaamiana MT, Partasasmita R. Kamarubayana L. 2019. Growth patterns of Shorea leprosula and Dryobalanops lanceolata in Borneo's forest managed with Selective Cutting with Line Replanting System. Biodiversitas 20: 1160-1165. Dryobalanops lanceolata is a species of plant in the family Dipterocarpaceae, which indigenous of Borneo. It is found in at least five protected areas (Kabilli-Sepilok Forest Reserve, Danum Valley Conservation Area, Ulu Temburong, Lambir, and Gunung Mulu National Parks), but is threatened elsewhere due to habitat loss. The demand for its timber is very high, so it requires conservation efforts while at the same time maintaining its productivity to meet the timber demand. One of the efforts to increase productivity of production forest in Indonesia is implementing Selective Logging with Line Replanting System (TPTJ). In this system superior species are planted in the planting lines. This study aimed to determine the growth of Shorea leprosula and Dryobalanops lanceolata planted in different planting line widths. Data of diameter increment of $S$. leprosula and D. lanceolata were obtained by observing 4 permanent sample plots (PUP) at concession areas of PT Balikpapan Forest Industries in Penajam Paser Utara, East Kalimantan, Indonesia. The results showed that the average diameter increment of $S$. leprosula and $D$. lanceolata at the planting line width of 3 meters was $1.47 \mathrm{~cm} / \mathrm{yr}$ and $0.74 \mathrm{~cm} / \mathrm{yr}$ respectively, and at the planting line width of 6 meters was $2.08 \mathrm{~cm} / \mathrm{yr}$ and $1.14 \mathrm{~cm} / \mathrm{yr}$ respectively. The differences in planting line width had very significant effect on the growth and diameter increment of $S$. leprosula, presumably due to the increase of light intensity to optimal level which accelerates stomata opening and transpiration rate, thus affecting the rate of photosynthesis.
\end{abstract}

Keywords: Dryobalanops lanceolata, light intensity, silviculture, Shorea leprosula, planting line

\section{INTRODUCTION}

The species of the family Dipterocarpaceae are dominant in tropical rainforests in Borneo, so they become the characteristic of Borneo's tropical rainforests. Shorea, better known as meranti (Eni et al. 2018), is one of the genera of the family Dipterocarpaceae which has the highest species diversity. One of the Dipterocarpaceae which is often exploited is Dryobalanops lanceolata, an endemic species of Borneo (Chung et al. 2013). Another species of dipterocarp, i.e., Tengkawang (Shorea sp) has also been exploited excessively, so its abundance has been declining, and this species is now rare (Eni et al. 2018). Because its timber is one of the most needed tropical forest commodities, it is very difficult to find in the market. In the world of commerce, the Meranti is divided into four major groups, namely: the red meranti, the yellow meranti, the white meranti, and the balau groups (Wahyu et al.). Shorea leprosula Miq. and Dryobalanops lanceolata are known in the world of international trade as red meranti.

Ashton (1982) reports that the distribution of these two species in Indonesia includes the islands of Borneo and Sumatra. Since the beginning of large-scale logging in the 1970 s, the demand for timber has always relied on natural forests, while the condition and extent of natural forests have been declining. The forest area of East Borneo has declined from 17,875,100 ha to $13,616,195$ ha (Sutisna 2006). The Forestry Planning Agency (2006) estimated the rate of forest destruction in East Borneo to be 376,159 ha annually. In an effort to reduce the area of damaged forests and maintain the potential of these two species, it is necessary to encourage people to plant them in the form of plantations. Marginal lands widely distributed in East Borneo have the potential to be used as land for the plantation of both species of Dipterocarpaceae (Yassir and Muntikauji 2007). An important factor in cultivating and managing plants is the knowledge of appropriate silvicultural techniques, such as land preparation and planting distance, based on the species planted.

In Indonesia three silvicultural systems have been applied, namely Indonesian Selective Cutting System (TPI), Indonesian Selective Cutting with Replanting System (TPTI), and Selective Cutting with Line Replanting System (TPTJ) (Na'iem et al. 2013). The third system (TPTJ) is one of the efforts for saving tropical forest in Indonesia, especially in increasing productivity and quality of production forest. TPTJ was previously called Indonesian Selective Logging with Intensive Replanting 
(TPTII) or better known as Intensive Silviculture (SILIN), because it implements intensive silvicultural techniques and planting superior target species in the replanting lines. Intensive silviculture is aimed at developing prospective forest, which is a plantation forest having high productivity, efficient utilization, effective management, stable ecosystem, and high biodiversity ((Na'iem 2014).

SILIN has been considered a new approach to increasing tropical forest productivity. It is a technique to increase the productivity by planting selected species, including Shorea leprosula, in replanting lines using some element of growth, such as good seed sources, optimum environmental manipulations (good land preparation, appropriate fertilization, and suitable light intensity), and reduction of forest product loss due to pests and diseases. Land preparation of SILIN was initiated by making a strip planting, three meters wide, free from tall trees so the sunlight can reach forest floor optimally ( $\mathrm{Na}$ 'iem et al. 2013).

Pilot projects of SILIN using meranti have been conducted in six forest concession areas in Indonesia since 2005. Preliminary results showed that target species were expected to have increment of about $10 \mathrm{~m}^{3} / \mathrm{ha} / \mathrm{yr}$. The examples of the target species were Shorea leprosula, $S$. parvifolia and S. Johorensis (Soekotjo 2009). Those species and S. Platyclados are good for enrichment planting in selective cutting with line replanting silvicultural system. Without enrichment planting with appropriate species, tropical rainforest will experience degradation and fragmentation (de Lacerd et al. 2012). It would be necessary to apply the next research about a combination of selected dipterocarp species and specific silviculture treatment to increase the productivity of tropical forest (Widyatno et al. 2011; Subiakto et al. 2016). Therefore, TPTJ still needs to be studied carefully, because when it is implemented on a large scale, it will prevent great economic losses and ecological risk.

The information on the influence of line width on the standing stock of $S$. leprosula and D. lanceolata in TPTJ is very needed for forest management plan with the principle of sustainable yield. This study aimed to determine the standing stock of S. leprosula and D. lanceolata planted in different planting line widths and to know the influence of the planting line width on the standing stock $S$. leprosula and D. lanceolata on the TPTJ system in the concession area of Timber Forest Products (IUPHHK) PT Balikpapan Forest Industries in the District of Penajam Paser Utara. This research is expected to find the optimal planting line width to improve the productivity of the forest with $S$. Leprosula and D. lanceolata species.

\section{MATERIALS AND METHODS}

\section{Study area}

This research was carried out at the TPTJ block of PT Balikpapan Forest Industries (PT. BFI) in Penajam Paser Utara District, East Kalimantan Province, Indonesia (116 23'57' E, 1 ${ }^{\circ} 7^{\prime} 15^{\prime}$ ' S) (Figure 1).

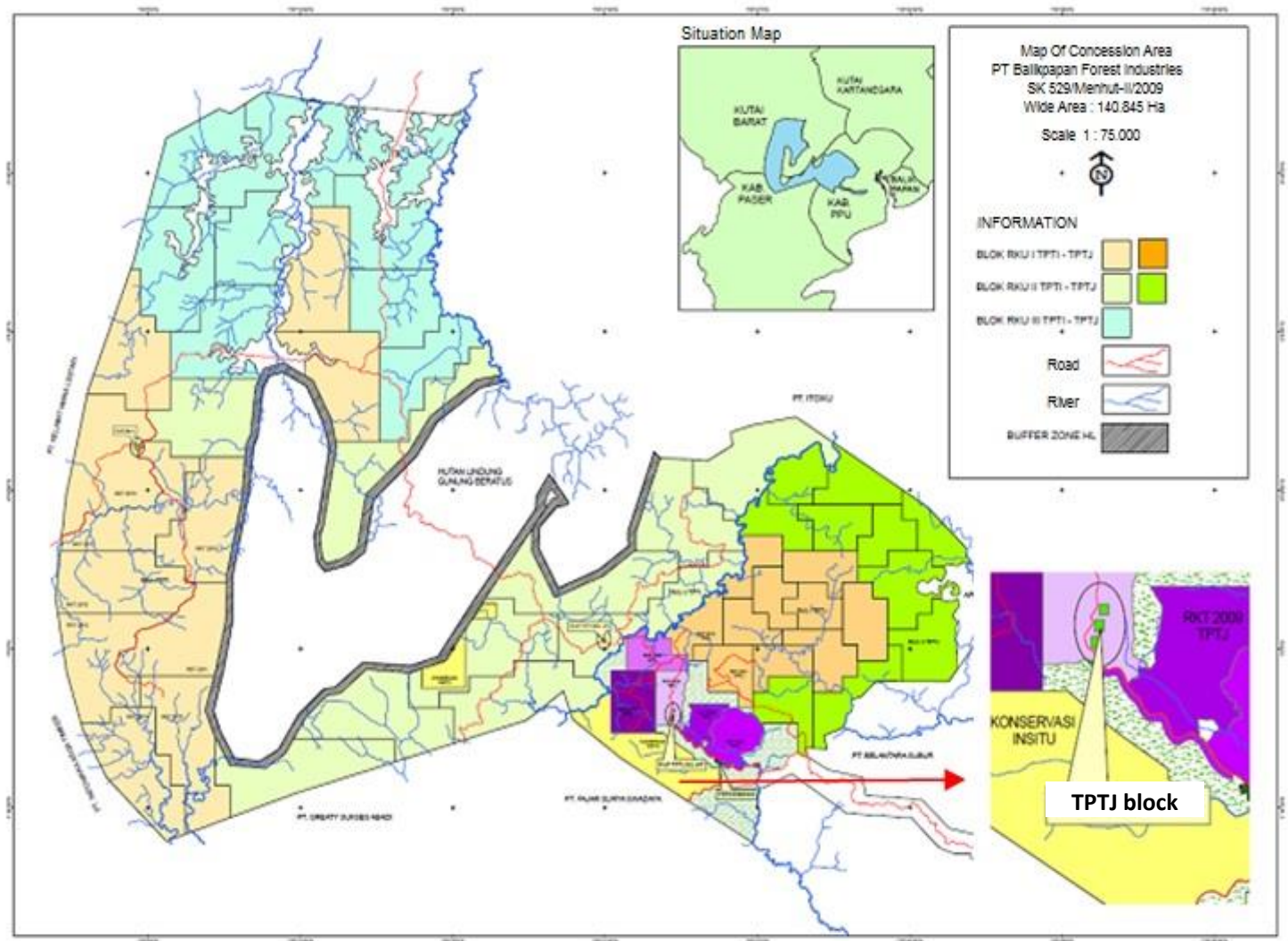

Figure 1. Research location at the TPTJ block of PT Balikpapan Forest Industries (PT BFI) in Penajam Paser Utara District, East Kalimantan Province, Indonesia 


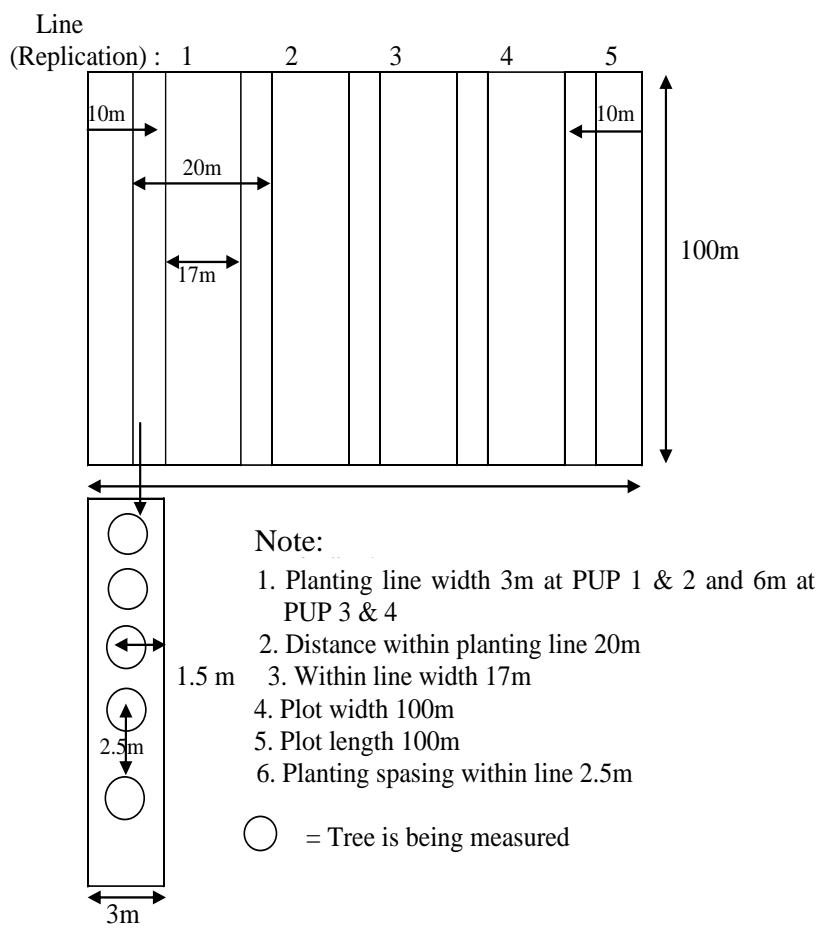

Figure 2. Research plot layout

The silviculture system which was used to manage forest area was TPTJ. In this system, the minimum tree's diameter at breast height (DBH) allowable to be harvested is $40 \mathrm{~cm}$ (Ministry of Forest 2009), and artificial regeneration should be conducted using selected dipterocarps in line planting system (Nguyen-the et al. 1998). The location has type A climate (Schmidt and
Ferguson) with mean annual rainfall of 2,316 mm year ${ }^{-1}$ and raining days of 125 days year ${ }^{-1}$. Materials used in this research were $S$. Leprosula and D. lanceolata saplings and trees, 1-7 years old, at the planting lines in the TPTJ block in the concession area of PT BFI. Equipment which was used consisted of work map, phi-band, Suunto clinometer, and measuring tapes.

\section{Procedures}

To determine the growth of $S$. leprosula and $D$. Lanceolata, 1-7-year-old saplings and trees planted at the planting lines on the TPTJ block. two-line widths were made, namely 3 meters and 6 meters. The tree growing parameters were measured at the 4 PUPs (permanent sample plots) measuring 100m x 100m (1 ha) each and had 5 planting lines as replication (Figure 2-3).

\section{Data analyses}

The growth parameters were calculated using the following formulas:

\section{The basal area of a tree}

The basal area of a tree was obtained with the following equation:

$$
\mathrm{g}=1 / 4 \pi \mathrm{d}^{2}
$$

Where:

$\mathrm{g}=$ basal area $\left(\mathrm{cm}^{2}\right)$

$\mathrm{d}=$ diameter of tree $(\mathrm{cm})$

$\pi=3.141592654$

While, the total tree basal area was obtained with the following equation:

$$
\begin{array}{cl}
\mathrm{G} & =\sum \mathrm{g} \\
\text { (trees) } & \mathrm{i}=1
\end{array}
$$

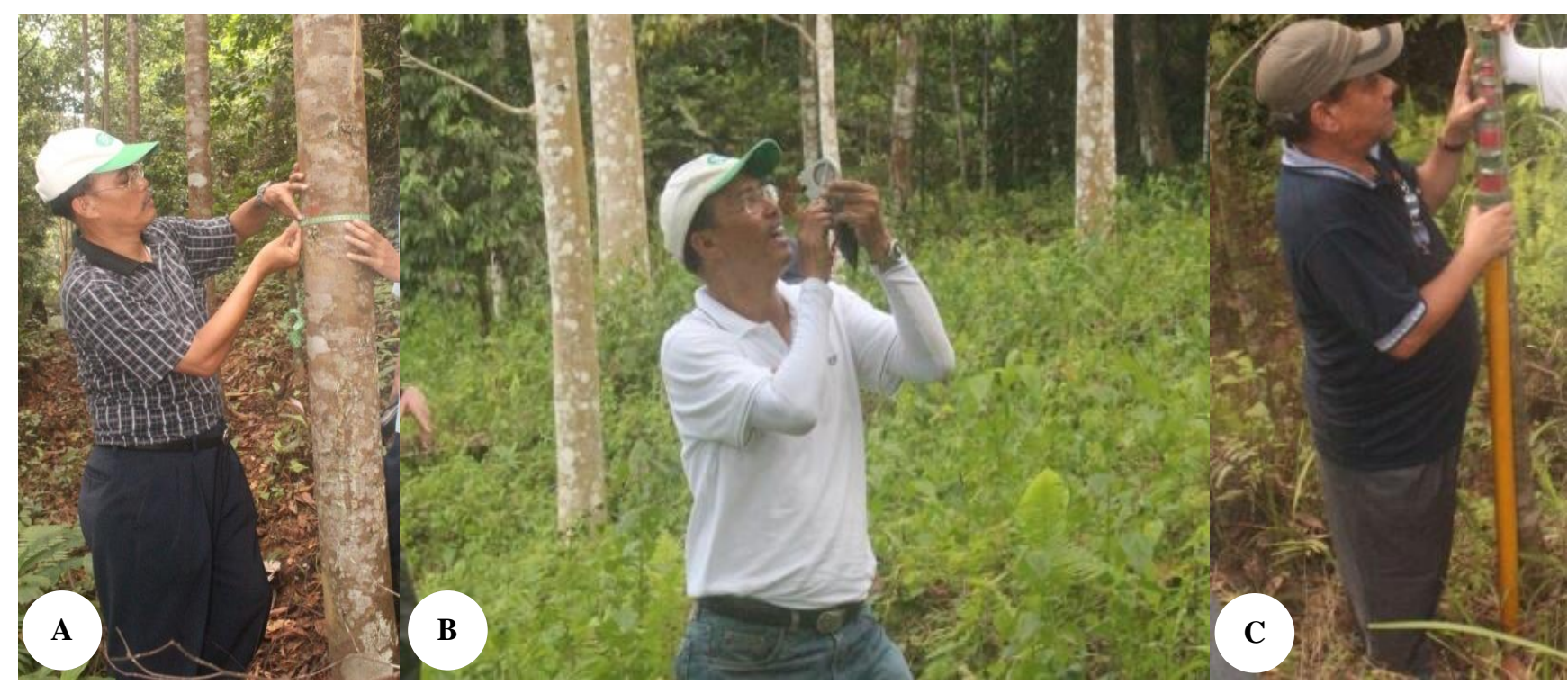

Figure 3. A. Measurement of tree diameter using phi-band, B. Measurement of height of the tree using clinometer, C. Measurement of height of the tree using measurement stick. 
Mean Annual Increment (MAI)

The calculation of the mean annual increment was based on a formula of Marsono (1987) as follows:

$$
\text { MAI Diameter }=\frac{\text { Dbh }}{\text { Age }}(\mathrm{cm} / \text { year }) / \text { Age }
$$

\section{Current Annual Increment (CAI)}

The calculation of the current annual increment was based on a formula of Prodan (1968) as follows:

$$
\begin{gathered}
\cdot \text { CAI diameter }=\frac{D n+1-D n}{T n+1-T n}=\frac{\Delta D}{\Delta T} \\
\cdot \text { CAI basal area }=\frac{g n+1-g n}{n+1-T n}=\frac{\Delta g}{\Delta T}
\end{gathered}
$$

Next, statistical tests were carried out to determine the differences in diameter increment and basal area of the trees at the different planting line widths, using t-test as follows:

$$
\begin{aligned}
& \mathrm{S}^{2}=\frac{\left(\mathrm{n}_{1}-1\right) \mathrm{S}_{1}^{2}+\left(\mathrm{n}_{2}-1\right) \mathrm{S}_{2}^{2}}{\left(\mathrm{n}_{1}-1\right)+\left(\mathrm{n}_{2}-1\right)} \\
& \mathrm{Sd}^{2}=\frac{\mathrm{n}_{1}+\mathrm{n}_{2}}{\mathrm{n}_{1} \mathrm{n}_{2}} \mathrm{~S}^{2} \\
& \mathrm{Ho}: \mu_{1}=\mu_{2} \\
& \mathrm{H} 1: \mu_{1} \neq \mu_{2} \\
& \mathrm{t}_{\text {hit }}=\frac{\overline{\mathrm{x}_{1}}-\mathrm{x}_{2}-}{\mathrm{Sd}}
\end{aligned}
$$

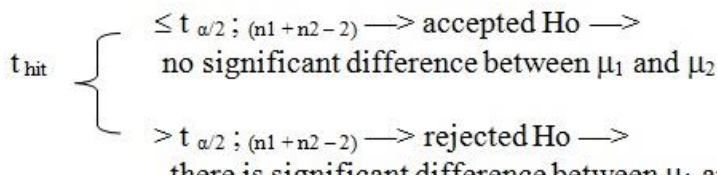

'Where:

$\mu$ 1: mean diameter increment $(\mathrm{cm} / \mathrm{yr})$ and basal area of population $\left(\mathrm{m}^{2} / \mathrm{ha} / \mathrm{yr}\right)$ at the 3 -meter-width planting lines

$\mu$ 2: mean diameter increment $(\mathrm{cm} / \mathrm{yr})$ and basal area of population $\left(\mathrm{m}^{2} / \mathrm{ha} / \mathrm{yr}\right)$ at the 6 -meter-width planting lines

$\mathrm{x} 1$ : basal area of the sample $\left(\mathrm{m}^{2} / \mathrm{ha}\right)$ at plots in the $3-$ meter-width planting lines

$\mathrm{x} 2$ : basal area of the sample $\left(\mathrm{m}^{2} / \mathrm{ha}\right)$ at the plots in the 6-meter-width planting lines

S1: models variance at 3-meter-width planting lines

S2: models variance at 6-meter-width planting lines

n1: number of sample plots models at 3-meter-width planting lines

n2: number of sample plots models at 6-meter-width planting lines

\section{RESULTS AND DISCUSSION}

\section{Diameter increment of $S$. leprosula and $D$. lanceonata}

The width of the planting lines had an effect on the pattern of growth and increase in stem diameter of $S$. leprosula and D. lanceolata (Figure 4).

The growth and increment of diameter of $S$. leprosula and D. lanceolata at 3 and 6-meter planting widths showed similar patterns, but those at planting width of 6 meters were higher than at 3 meters. In the wider planting line, the distance among trees is wider, so the competition of nutrients and light requirements for plants is relatively smaller. The wider planting line results in higher diameter and height growth than the narrow planting line (Lepe and Noor 1992).

These data indicate that $S$. leprosula and D. lanceolata are tolerant to the availability of sunlight. Hence, they can be easily established in open planting area that has hightemperature stress in the early plantation establishment (Pedraza and Williams-Linera 2003).

\section{Basal area growth and increment of S. leprosula and $D$. lanceonata}

While the patterns of growth and increment of stem diameter of $S$. leprosula and $D$. lanceolata in planting width of $6 \mathrm{~m}$ are similar to those of $3 \mathrm{~m}$, the growth and increment of the basal area show different patterns between the two-line widths (Figures 5).

Figures 5 show that the increase in the basal area of $S$. leprosula in the $3 \mathrm{~m}$ and $6 \mathrm{~m}$ planting line width was not significantly different from each other until the 3rd year, and for D. lanceolata until 2.5 years after planting. In the 4th to 6th years, the basal area increase of the $S$. leprosula tree was higher at the planting line width of $3 \mathrm{~m}$ thanof $6 \mathrm{~m}$. In D. lanceolata, the increase of basal area was higher in 3 $\mathrm{m}$-width lines than in $6 \mathrm{~m}$, but the difference was not significant. The tree basal area increment is not only determined by the diameter increment but by the number of trees per unit area. Tree basal area increment culminates slower than its diameter increment (Ruchaemi 2013). According to Herbagung (1991), the growth rate of a tree is a result of genetic factors, environmental and cropping management. In this study, planting line width as an environmental factor and management techniques affect tree growth (Herbagung 1996).

Light intensity in the forest floor will affect the process of photosynthesis in trees. Optimal light intensity on the leaves will accelerate the opening of stomata and transpiration rate, thus affecting the rate of photosynthesis. The increased rate of photosynthesis will accelerate the growth of diameter and plant height. The opening of canopy is essential for successful regeneration. Research on shade effects shows that the possibility of dipterocarp requires some light radiation greater than direct light radiation (Aston 1982; Newman et al. 1996). Shorea leprosula has been known as Meranti tembaga which is tolerant to water stress and also known as light-demanding species in the early stage of growth. This species also has a wide range of geographical distribution (Appanah and Weiland 1993; Kiswanto 2008). 


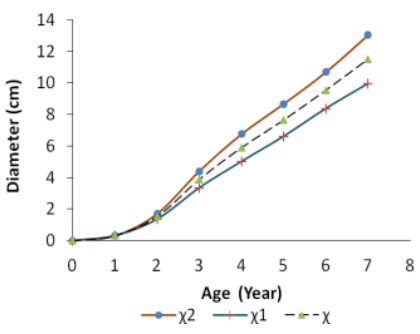

A

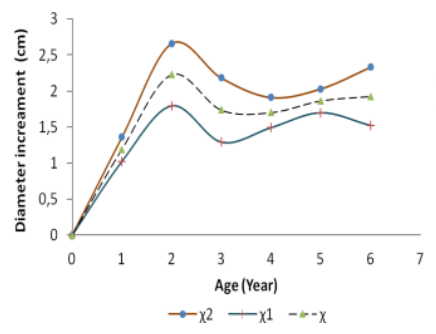

B

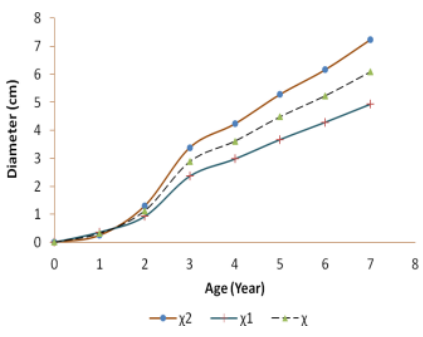

C

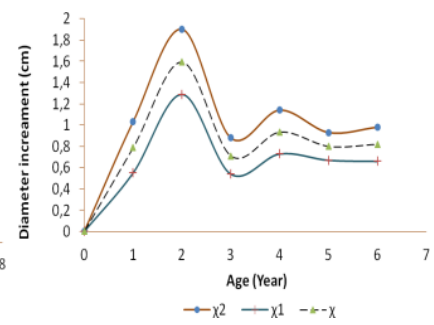

D

Figure 4. A. Diameter of $S$. leprosula at different planting ages, at planting line widths of $3 \mathrm{~m}$ and $6 \mathrm{~m}(\chi 1=$ diameter at 6 meters planting line, $\chi 2=$ diameter at 6 meters planting line, $\chi=$ average $(\chi 1+\chi 2))$; B. Diameter increment of $S$. leprosula at different planting ages, at planting line widths of $3 \mathrm{~m}$ and $6 \mathrm{~m}(\chi 1=$ diameter at 6 meters planting line, $\chi 2=$ diameter at 6 meters planting line, $\chi=$ average $(\chi 1+\chi 2))$; C. Diameter of D. lanceolata at different planting ages, at planting line widths of $3 \mathrm{~m}$ and $6 \mathrm{~m}(\chi 1=$ diameter at 6 meters planting line, $\chi 2=$ diameter at 6 meters planting line, $\chi=$ average $(\chi 1+\chi 2))$; D. Diameter Increment of $D$. lanceolata at different planting ages, at planting line widths of $3 \mathrm{~m}$ and $6 \mathrm{~m}\left(\chi 1=\right.$ diameter at 6 meters planting line, $\chi^{2}=$ diameter at 6 meters planting line, $\chi=$ average $\left.(\chi 1+\chi 2)\right)$

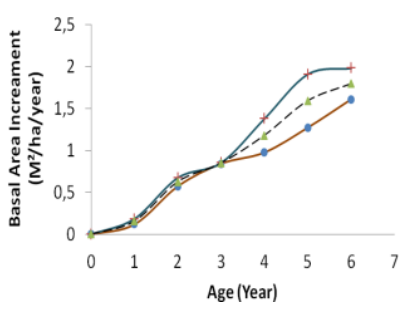

A

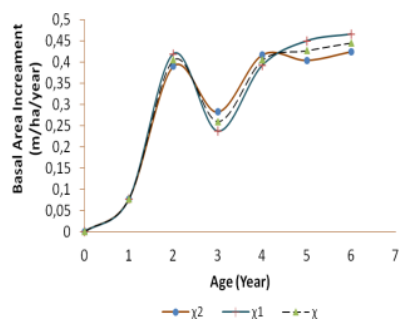

B
Figure 5. A. Basal area increment of $S$. leprosula at different planting ages, at planting line widths of $3 \mathrm{~m}$ and $6 \mathrm{~m}(\chi 1=$ diameter at 6 meters planting line, $\chi 2=$ diameter at 6 meters planting line, $\chi=$ average $(\chi 1+\chi 2))$; B. Basal area increment of $D$. lanceolata at different planting ages, at planting line widths of $3 \mathrm{~m}$ and $6 \mathrm{~m}$ at PT BFI $(\chi 1=$ diameter at 6 meters planting line, $\chi 2=$ diameter at 6 meters planting line, $\chi=$ average $\left.\left(\chi 1+\chi^{2}\right)\right)$

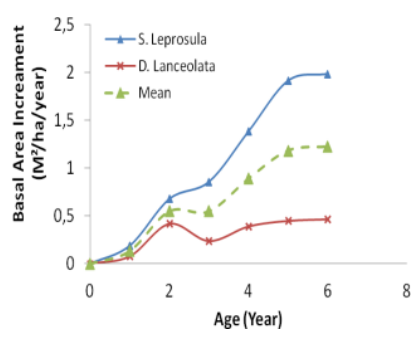

A

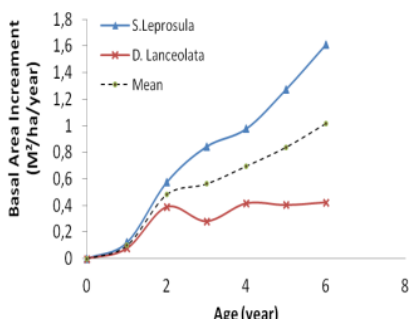

B
Figure 6. A. Basal area increment of $S$. leprosula and $D$. lanceolata at different planting ages, on planting line width of 3 m. B. Basal area increment of $S$. leprosula and D. lanceolata at different planting ages, on planting line width of $6 \mathrm{~m}$

The pattern of the basal area increment of S. Leprosula and $D$. Lanceolata on both planting line widths was almost the same. The basal area increment of $S$. leprosula was higher than that of D. Lanceolata, both at $3 \mathrm{~m}$ and $6 \mathrm{~m}$ planting line widths (Figure 6).
Figures 6 shows that $S$. leprosula had higher growth, diameter increment and basal area than $D$. lanceolata, both at planting lane widths of $3 \mathrm{~m}$ and $6 \mathrm{~m}$. It is assumed that the land suitability is better for $S$. leprosula than for $D$. lanceolata at both lanes.

According to Ruchaemi (2013), in the tropical area, the growth diameter of broadleaf trees happens all year long. The growth of trees' diameter is influenced by its position within the stand. The suppressed trees start and end their growth generally faster than the dominant trees. The highest point of diameter increment on stand lifetime occurs faster than that of height increment. Through the arrangement of growing space and fertilization, the highest point can be slowed or even stopped. Diameter increment on the trunk close to the ground is greater that of the upper parts (Ruchaemi 2013).

The average diameter increment of $D$. lanceolata on 3 $\mathrm{m}$ line was $0.74 \mathrm{~cm} /$ year and on $6 \mathrm{~m}$ line was 1.14 $\mathrm{cm} /$ year, while that of $S$. leprosula was higher than $D$. lanceolata, which was $1.47 \mathrm{~cm} /$ year on the $3 \mathrm{~m}$ lane and $2.09 \mathrm{~cm} /$ year on the $6 \mathrm{~m}$ line. The less optimal growth may be due to space, substrate or nutrient competition during the exponential phase. The light intensity has a significant effect on the improvement of plant height. Plants in the low light intensity significantly have less growth than plants in the high light intensity because the reduction of light intensity results in reduction of leaf production and leaf area.

In another study, Kiswanto (2008) found that $D$. lanceolata had diameter increment of $2.61 \mathrm{~cm} /$ year. On his research, D. lanceolata had larger increase of diameter in the first year than S. leprosula and S. Parvifolia, probably because in his study site, $D$. lanceolata had bigger seed sizes and so they were more suitable to grow and easier to adapt to the planting site conditions.

It can be concluded that $S$. leprosula and $D$. lanceolata grew better in $6 \mathrm{~m}$-width lines than in $3 \mathrm{~m}$-width lines, and $S$. leprosula had higher growth than $D$. lanceolata. It is recommended the line width for TPTJ should be 6 meters. 


\section{ACKNOWLEDGEMENTS}

This work was supported by Faculty of Agriculture, The University of 17 August 1945 Samarinda, Indonesia and partially funded by PT. Balikpapan Forest Industries, Indonesia. We would like to give the deepest appreciation to Afif Ruchaemi and Rudianto Amirta (Dean of Forestry Faculty, Mulawarman University, Samarinda) for giving guidance of technique and method in doing this work. In addition, we also thank the Graduate Program of Forestry Faculty, Mulawarman University for allowing us to conduct this research. We would also like to thank the R\&D staff of PT. Balikpapan Forest Industries for their help in carrying out this experiment especially for frequently maintaining and measurement on this research.

\section{REFERENCES}

Appanah S, Weinland G. 1993. Planting quality timber trees in Peninsula Malaysia. Forest Research Institute Malaysia. Kepong. Malayan Forest Record. No. 38.

Ashton PS. 1982. Flora Indo-Malayana. Seri I. 9 (2): 237-552[Indonesian] Chung AYC, Maycock CR, Khoo E, Hastie A, Nilus R, Majapun R, Kimjus K, Chey VK. 2013. New records of insect associated with Borneo endemic dipterocarp seedlings. J Trop Forest Sci 25 (1): 5-11

de Lacerd AEB, Junior FWA, Scolforo JRS, de Mello JM, de Oliveira AD, de Carvalho LMT, Calegário A, Filho, ACF. 2012. Sustainable forest management of native vegetation remnants in Brazil. In: Martín-García J, Diez JJ (eds.). Sustainable Forest Management Case Studies. InTech, Rijecka, Croatia.

Eni A, Dewantara I, Sisillia L. 2018. Identification of tengkawang (Shorea spp) species as natural days of tenun ikat Kapuas Hulu Regency West Borneo. J Hutan Lestari. 6 (1): 7-15 [Indonesian].

Herbagung. 1996. Model of growth in diameter and plant height Eucalyptus deglupta B1. in Benakat South Sumatra dan Kenangan East Borneo. Bull Penelitian Hutan 559: 15 - 32. [Indonesian]

Kiswanto. 2008. Natural Youth Growth and Crops in the Test Area of the Intensive TPTI System. [Thesis]. Faculty of Forestry, Mulawarman University, Samarinda. [Indonesian].
Lepe D, Noor M. 1992. Trial type and spacing of three species of meranti. Jurnal Penelitian Hutan Tropika Samarinda. Wanatrop. [Indonesian]

Ministry of Forestry. 2009. The guidance of silviculture system in the forest production area to manage forest product: No. P.9/VI/BPHA/2009. Ministry of Forestry. Jakarta.

Na'iem M, Widiyatmo M, Al-Fauzi Z.2013. Progeny test of Shorea leprosula as key point to increase productivity of secondary forest in PT Balik Papan Forest Industries, East Kalimantan, Indonesia. Environmental Sciences Procedia. Elsevier, Nederland.

Na'iem M. 2014. Improved national forest productivity based on rehabilitation: efficient use of forest areas. 50 years of the Faculty of Forestry, Gajah Mada University: Indonesian Forest Emergency; Realizing Indonesia's New Forestry Architecture. Wana Aksara. Tangerang. [Indonesian]

Newman MF, Burges PF, Whitmore TC. 1996. Manual of dipterocarps for forester: Borneo Island light hardwoods, Anisoptera, ParaShorea, Shorea (Red, White and Yellow Meranti). Royal Botanic Garden Edinburgh \& Cifor. Jakarta.

Nguyen-The N, Favrichon V, Sist P, Houde L, Bertault JG, Fauvet N. 1998. Growth and mortality patterns before and after logging. In: Bertault JG, Kadir K, editors. Silvicultural research in a lowland mixed dipterocarp forest of East Kalimantan. CIRAD-forest, Forda \& PT. Inhutani I, Jakarta.

Pedraza RA, Williams-Linera G. 2003. Evaluation of native tree species for the rehabilitation of deforested areas in a Mexican cloud forest. New Forests 26: 83-99.

Prodan M. 1968. Forest Biometrics. Pergamon Press, Oxford, London.

Ruchaemi A. 2013. The science of forest growth. Mulawarman University Press, Samarinda. [Indonesian]

Soekotjo. 2009. Intensive silviculture techniques (SILIN). Gajah Mada University Press, Yogyakarta. [Indonesian]

Subiakto A, Rachmat HH, Sakai C. 2016. Choosing native tree species for establishing man-made forest: A new perspective for sustainable forest management in changing world. Biodiversitas 17: 620-625

Widyatno S, Purnomo, Soekotjo, Na'iem M, Hardiwinoto S. 2011. Growth of selected Shorea spp. in secondary tropical rainforests: the effect of silvicultural treatments to improve the quality of growth Shorea spp. J Penelitian Hutan Konservasi Alam 8 (4): 373-383 [Indonesian]

Yassir I, Mitikauji Y. 2008. Effect of land preparation on the growth of Shorea leprosula Miq., and Shorea balangeran (Korth) Burck on blady grass areas in Samboja-East Borneo). J Res Dipterocarp 1 (1): 23-35 [Indonesian] 